\title{
PERANAN GURU PKN DALAM PEMBENTUKAN KEDISIPLINAN SISWA DI MAN MALANG 1
}

\author{
Kurniati, Rohmad Widodo, Budiono \\ FKIP Universitas Muhammadiyah Malang, Indonesia \\ Email: nia_isjueb@yahoo.co.id
}

\begin{abstract}
ABSTRAK
Sekolah sebagai lembaga pendidikan formal merupakan komponen yang sangat penting dalam mengembangkan sikap disiplin siswa. Karena disekolah siswa dibelajarkan tentang tata tertib dan kedisiplinan, aturan atau tata tertib sekolah berfungsi supaya siswa menjadi disiplin. Secara sederhana disiplin dapat diartikan sebagai sikap patuh, tata dan tertib terhadap peraturan yang berlaku disekolah. Penelitian ini menggunakan pendekatandeskriptif kualitatif yang membahas tentang peranan Guru PKn dalam membina kedisiplinan siswa. Peran disiplin memang sangat penting bagi setiap individu, apalagi bagi peserta didik. Karena sikap disiplin yang muncul dari kesadaran diri seorang anak akan mengantarkan kepada kesuksesan belajar dan tentunya sikap disiplin itu didukung oleh kesadaran mentaati aturan, norma-norma dan tata tertib yang berlaku agar siswa menjadi individu yang tertib, teratur dan disiplin dalam berbagai hal. Tujuan penelitian ini adalah: (1) Mendeskripsikan peranan Guru PKn dalam membina kedisiplinan siswa, (2) Mendeskripsikan kendala yang dihadapi oleh Guru PKn dalam membina kedisiplinan siswa, (3) Mendeskripsikan solusi yang dilakukan oleh Guru PKn dalam mengatasi pelanggaran kedisiplinan siswa. Dari penelitian ini diperoleh kesimpulan yaitu: (1) Guru PKn MAN Malang 1 telah membina kedisiplinan siswa dengan baik, (2) Kendala dari pelaksanaan disiplin sekolah kurang disadari oleh siswa dan cenderung melakukan pelanggaran tata tertib sekolah dan kurang adanya komunikasi antara pihak sekolahdanguru-guru dengan orang tua siswa terhadap masalah kedisiplinan siswa tetapi hanya sebagian dari guru-guru saja. (3) Solusi yang dilakukan dalam mengatasi kedisiplinan siswa, Guru PKn tetap melakukan pengawasan dan selalu mencaritahu permasalahan yang ada pada diri peserta didik dan tentunya pihak sekolah jugaserta guru-guru dan karyawan yang ada di MAN Malang 1 berupaya agar saling kerjasama dalam membina kedisiplinan siswa.Oleh karena itu, tidak hanya petugas tatib saja yang membina kedisiplinan siswa tetapi semua civitas akademik yang ada di MAN Malang 1 harus menyadarinya serta ikut bertanggung jawab yang berkaitan dengan kedisiplinan siswa. Maka dari itu pihak sekolah harus lebih mengefektifkan peraturan tata tertib lebih baik lagi dengan memberikan sanksi kepada siswa yang melakukan pelanggaran agar siswa tidak melanggar peraturan tata-tertib sekolah.
\end{abstract}

Kata kunci : Guru, Siswa, Kedisiplinan.

\begin{abstract}
School is formal education institution which is a very important component in developing the students discipline. Since in school the students are taught about the order and discipline, rules or school rules which still work in order to make the students being discipline. Simply discipline can be interpreted as a submissive attitude, order and discipline of the school regulations.This study used a qualitative descriptive approach which discusses about the role of Citizenship teachers in building students discipline. The role of discipline is very important for each individual, especially for the learners. Because of the discipline which appear from a child's self-awareness will lead to the success of learning and actually discipline was supported by awareness obey the rules, norms and rules that applied in order to make the students become individuals who orderly, organized
\end{abstract}


and discipline in various ways. The purpose of this study were:(1) Describing the role of Citizenship teachers in building the students discipline, (2) Describing the constraints faced by Citizenship teachers in building the students discipline, (3) Describing the solution that applied by Citizenship teachers in addressing violations of the student discipline.From this study we can concluded that: (1) Citizenship teachers at MAN Malang 1 has been built the students with good discipline, (2) The problems in the implementation of school discipline neglected by students and tend to commit violations of school rules and lack of communication among the school and teachers the teacher with students parents on disciplinary problems but only several teachers. (3) The solution was done in addressing student discipline; Citizenship teachers remain to observe and always seek out the existing problems in self-learners and actually also the school and the teachers and employees in MAN Malang 1 should do mutual cooperation in student discipline. Therefore, not only the Rule officer who build the students discipline but all the academic community in Malang MAN 1 should be aware of and take responsibility related to students discipline. Thus the school should streamline further about the disciplinary rules by giving sanction to the student who commits an offense so the students do not violate the rules of school discipline.

Keywords : Teacher, Students, Discipline.

\section{PENDAHULUAN}

Sekolah sebagai lembaga pendidikan formal merupakan komponen yang sangat penting dalam mengembangkan sikap disiplin siswa, karena disekolah siswa dibelajarkan tentang tata tertib dan kedisiplinan. Aturan atau tata tertib sekolah berfungsi agar siswa menjadi disiplin. Secara sederhana disiplin dapat diartikan sebagai sikap patuh, tata dan tertib terhadap peraturan yang berlaku di sekolah.

Pemberlakuan disiplin menjadikan siswa dapat belajar beradaptasi dengan lingkungan yang baik sehingga muncul keseimbangan diri dalam berhubungan dengan orang lain. Disiplin sekolah harus dilaksanakan dengan baik konsekuen dan konsisten. Kepala sekolah, guru dan pegawai lainnya yang ada dalam komponen-komponen sekolah ikut memberi teladan yang baik dalam menerapkan disiplin sekolah.

Komponen penting selain sekolah yaitu guru, dimana guru mempunyai peranan besar dalam membina kedisiplinan siswa. Peranan Guru PKn sangat penting, selain memberi materi pelajaran Guru PKn pun

Jurnal Civic Hukum Volume 3, Nomor 2, November 2018, hal. 163-173 berperan dalam membina kedisiplinan yang ada dalam diri siswanya seperti disiplin waktu, disiplin berpakaian dan berperilaku disiplin yang berbasiskan nilai moral, seorang guru harus bisa memberikan pembinaan disiplin siswanya melalui keteladanan, guru juga harus memberi dorongan kearah yang lebih baik. Guru sendiri harus teladan dan memberikan contoh yang baik kepada siswanya.

Peranan Guru PKn yaitu harus mampu membawa anak didiknya menjadi manusia Indonesia yang memiliki rasa kesadaran yang tinggi dalam melaksanakan tugas dan tanggung jawabnya sebagai warga negara yang baik. Proses pendidikan dapat berhasil apabila adanya upaya penciptaan suasana belajar mengajar yang kondusif, dimana didalamnya harus tertanam perilaku disiplin yang baik, untuk itu diperlukan peran dan figur seorang guru yang bias bertanggung jawab dalam mengajar disekolah dengan membina dan menjadi teladan bagi siswanya khususnya dalam hal kedisiplinan.

Dalam pengembangan disiplin disekolah perlu mendapat dukungan dari berbagai pihak terutama guru dan orang 
tua. Guru yang setiap hari mengajar siswa dikelas dan berinteraksi secara langsung dengan siswa dapat diharapkan bisa membina kedisiplinan dengan baik. Orang tua sebagai pendidik, pengawas dan pengontrol ketika dirumah juga diharapkan dapat membimbing, mengawasi dan mendidik anaknya supaya tidak melakukan tindakan-tindakan yang merugikan dirinya sendiri dan orang tua.

Disiplin sebagai kondisi yang tercipta dan terbentuk melalui proses dari serangkaian perilaku yang menunjukkan nilai-nilai ketaatan, kepatuhan, kesetiaan, keteraturan atau ketertiban. Nilai- nilai tersebut telah menjadi bagian perilaku dalam kehidupannya. Perilaku itu tercipta melalui proses binaan melalui keluarga, pendidikan dan pengalaman (Prijodarminto, 1994:23).

Disiplin merupakan sesuatu yang menyatu di dalam diri seseorang. Bahkan, disiplin itu sesuatu yang menjadi bagian dalam hidup seseorang, yang muncul dalam pola tingkah lakunya sehari-hari. Disiplin terjadi dan terbentuk sebagai hasil dan dampak proses pembinaan cukup panjang yang dilakukan sejak dari dalam keluarga dan berlanjut dalam pendidikan disekolah. Keluarga dan sekolah menjadi tempat penting bagi pengembangan disiplin seseorang.

Pembentukan disiplin terjadi karena disiplin akan tumbuh dan dapat dibina melalui latihan, pendidikan, penanaman, kebiasaan dan keteladanan. Pembinaan itu dimulai dari lingkungan keluarga sejak kanak-kanak. Disiplin juga diproses melalui pembinaan sejak dini, sejak usia muda, dimulai dari keluarga dan pendidikan. (Prijodarminto, 1994:15)

Berdasarkan hasil pengamatan (observasi) yang sudah dilakukan. Di Madrasah Aliyah Negeri Malang 1, masih banyak adanya pelanggaran-pelanggaran tata tertib sekolah yang dilakukan oleh siswa. Bentuk pelanggaran tersebut diantaranya: Siswa terlambat datang ke Madrasah, tidak masuk tanpa keterangan, mengeluarkan baju, keluar masuk ketika KBM berlangsung, tidak memakai atribut dan memakai sepatu di luar ketentuan sekolah.

Dari berbagai bentuk pelanggaran sekolah yang dilakukan oleh siswa di MAN Malang 1, maka guru dan pihak sekolah harus bisa menerapkan tentang peraturan dan tata tertib sekolah lebih efektif lagi, supaya tidak terjadinya pelanggaran terutama masalah kedatangan siswa yang terlambat dan sering tidak membawa atau memakai seragam yang tidak sesuai dengan ketentuan sekolah, dari itu perlu adanya pengawasan dari berbagai pihak sekolah terhadap siswa supaya siswa tidak melakukan pelanggaran terhadap peraturan atau tata tertib yang dibuat oleh sekolah.

Berdasarkan uraian diatas, penulis ingin melakukan penelitian untuk mengkaji sejauh mana peranan Guru PKn dalam membina kedisiplinan siswa di MAN Malang 1, maka dari itu penulis ingin melakukan penelitian dengan judul: "Peranan Guru PKn dalam Pembentukan Kedisiplinan Siswa di MAN Malang 1”

\section{METODE}

Dalam penelitian ini, jenis penelitian yang digunakan adalah pendekatan deskriptif kualitatif. Artinya data yang dikumpulkan bukan berupa angka-angka, melainkan data tersebut berasal dari datadata, wawancara, catatan lapangan, dokumen pribadi, dan dokumen resmi lainnya. Sehingga yang menjadi tujuan dari penelitian kualitatif ini adalah menggambarkan realita empirik di balik 
fenomena secara mendalam, rinci dan tuntas. Oleh karena itu, penggunaan pendekatan kualitatif dalam penelitian ini adalah dengan mencocokkan antara datadata yang telah ada dengan kenyataan yang ada di lapangan.

Metode Penelitian kualitatif sebagai prosedur penelitian yang menghasilkan data deskriptif berupa kata-kata tertulis, lisan dan orang-orang yang dapat diamati melalui metode penelitian deskriptif. Penelitian ini bermaksud untuk membuat diskripsi atau gambaran secara tertulis mengenai kenyataan yang sesungguhnya ada dengan teknik pengumpulan datanya, tidak di ubah dengan bentuk simbol atau bilangan.

Menurut Zuriah (2009:92), penelitian kualitatif bersifat generating theory bukan hypothesis testing sehingga teori yang dihasilkan berupa teori substantif. Penelitian kualitatif memerlukan ketajaman analisis, objektivitas, sistematis, dan sistemik sehingga di peroleh ketepatan dalam interprestasi, sebab hakikat dari sesuatu fenomena atau gejala bagi penganut penelitian kualitatif adalah totalitas atau Gestalt.

Jenis penelitian dalam penelitian ini adalah menggunakan pendekatan kualitatif. Penelitian yang lebih bersifat deskriptif sehingga metode kualitatif lebih mudah apabila berhadapan dengan kenyataan ganda. Jenis dan pendekatan kualitatif ini bertujuan untuk mencari data-data tentang Peranan Guru PKn dalam membina kedisiplinan siswa di MAN Malang 1.

\section{HASIL DAN PEMBAHASAN}

Peranan Guru PKn dalam membina kedisiplinan siswa di MAN Malang 1

Peranan guru sebagai pendidik bagi pembentuk generasi yang bermoral pada masa sekarang dan masa akan datang adalah sangat penting. Dimana guru bukan saja menyampaikan ilmu tetapi membentuk insan yang berketrampilan dari segi intelek, rohani, emosi, jasmani dan spiritual. Guru yang memainkan peranan yang berkaitan dengan memberi bantuan dan semangat, memerhati dan mendisiplinkan anak didik supaya patuh terhadap peraturan-peraturan sekolah dan norma hidup dalam keluarga dan masyarakat.

Peranan guru sangat besar karena secara langsung guru merupakan seseorang yang langsung berinteraksi dengan siswa dan melaksanakan transfer ilmu pengetahuan kepada siswa. Sebagai seorang pendidik guru mempunyai tanggung jawab yang besar dalam mewujudkan apa yang menjadi tujuan dari pendidikan.

Siswa terkadang sering datang terlambat ke sekolah dikarenakan beberapa alasan tertentu. Dalam hal ini peneliti ingin mengetahui bagaimana peranan Guru PKn dalam meningkatkan kedisiplinan siswa.

Adanya interaksi yang baik antara guru dan siswa dapat menciptakan situasi belajar mengajar yang baik. Siswa didalam interaksi belajar mengajar adalah subjek yang akan mencapai tujuan pembelajaran dalam bentuk hasil belajar. Kegiatan proses mengajar tidak lain adalah untuk menanamkan sejumlah norma kedalam jiwa anak didik. Semua norma diyakini mengandung kebaikan dan perlu ditanamkan kedalam jiwa anak didik melalui peranan guru dalam pengajaran.

Dalam hal ini yang harus diperhatikan adalah karakteristik siswa, baik karakteristik umum maupun karakteristik khusus, karena di MAN Malang 1ini terdapat karakteristik siswa yang berbedabeda, dengan perbedaan karakteristik tersebut maka pihak sekolah harus menerapkan lebih baik lagi tentang peraturan-peraturan yang harus 
dilaksanakan dan dipatuhi oleh siswa, karena tidak menutup kemungkinan kalau perbedaan karakter siswa itu dapat memberikan dampak/pengaruh negatif bagi siswa lain, kecuali pihak sekolah memang benar-benar telah menerapkan peraturan dan tata tertib sebaik mungkin untuk menghindari hal-hal yang bersifat negatif kepada siswa.

Seorang guru harus dapat menempatkan diri sebagai orang tua kedua bagi peserta didik, dengan mengemban tugas yang dipercayakan orangtua kandung/ wali siswa dalam jangka waktu tertentu. Untuk itu penanaman terhadap jiwa dan watak siswa diperlukan agar dapat dengan mudah memahaminya, karena itu merupakan tugas guru sebagai orang tua kedua bagi peserta didik.

Pelaksanaan peraturan sekolah sangat berpengaruh terhadap perilaku siswa. Dalam tata tertib, setiap siswa akan belajar mengetahui perilaku yang sesuai dan yang tidak sesuai untuk dilakukan. Apabila penerapan peraturan sekolah di MAN Malang 1 dirasa cukup ketat dan konsisten, seorang siswa akan berupaya lebih tertib lagi, karena jika tidak ada peraturan sekolah yang ketat maka siswa cenderung tidak tertib dan tidak disiplin. Sekolah yang mengembangkan tata tertib secara terencana dan dilaksanakan dengan baik, maka sekolah tersebut ikut memberikan konstribusi bagi pembentukan perilaku siswa yang baik sesuai dengan nilai-nilai yang ditanamkan kepadanya.

Pembelajaran yang diadakan disekolah bertujuan untuk mencapai adanya perubahan tingkah-laku. Perubahan perilaku siswa merupakan hasil proses pembelajaran, dengan demikian tata tertib yang ditanamkan, dilatih dan dibiasakan, akan berubah menjadi kebiasaan yang baik pula bagi siswa.
Perubahan perilaku dan sikap disiplin siswa nampak setelah beberapa kali pertemuan selama pelajaran PKn berlangsung. Perubahan tersebut tentunya berdampak positif bagi siswa karena siswa yang ramai ketika pelajaran PKn ditegur dan diberikan sanksi secara langsung oleh Guru PKn. Sanksi tersebut diharapkan dapat memberikan efek jera kepada siswa agar tidak mengulang perbuatannya lagi. Hal tersebut dapat dijadikan suatu pelajaran oleh siswa yang tidak tertib didalam kelas agar pada pertemuan selanjutnya siswa bisa lebih disiplin. Tetapi tidak hanya sanksi saja yang diberikan kepada siswa, siswa harus tetap diawasi agar tidak melakukan pelanggaran-pelanggaran disekolah.

Dari segi tata tertib juga harus dilaksanakan secara efektif agar setiap siswa tahu dan paham bahwa setiap perbuatan itu ada konsekuensi yang harus dijalani, sehingga siswa diharapkan paham terhadap peraturan dan tata tertib yang ada disekolah. Merubah tingkah-laku seorang anak dari kelakuan yang tidak baik menjadi lebih baik, misalnya membuat sebuah aturan sekolah agar para siswa dibina dan mendorong sikap kedisiplinan siswa.

Menegakkan tata tertib sekolah yang ketat dan konsisten membuat siswa berusaha untuk taat dan patuh pada peraturan sekolah. Mungkin pada tahap awal mereka hanya taat dan patuh karena ada tekanan atau rasa takut kepada guru maupun sanksi. Tetapi hal seperti itu dapat berubah menjadi suatu pelajaran yang sangat berharga dan disiplin akan menjadi kebiasaan bagi mereka, karena dapat diterima dan diterapkan secara pelan-pelan.

Pendekatan secara individual kepada anak didik mempunyai arti penting bagi pengajaran, karena dengan melakukan pendekatan kepada peserta didik seorang 
guru memerlukan strategi yang harus dilakukan, dengan strategi itu maka diharapkan dapat membantu guru dalam menangani berbagai permasalan yang dilakukan oleh peserta didik.

Dari hasil wawancara yang dilakukan oleh peneliti dengan Guru PKn bahwa sikap disiplin tidak hanya disampaikan ketika menyampaikan materi saja, tetapi setiap waktu harus ditanamkan pada masing-masing peserta didik, dengan begitu peserta didik menjadi terbiasa terhadap perilaku disiplin di sekolah. Jadi Guru PKn sangat berperan penting dalam pembinaan disiplin siswa disekolah, karena Guru PKn tugasnya bukan hanya mengajar saja tapi mendidik siswa-siswinya. Peranan utama guru disekolah adalah menyampaikan ilmu pengetahuan kepada anak didiknya, untuk itu perlu beberapa hal yang harus diperhatikan oleh seorang guru dalam menentukan strategi apa yang akan dilakukan sebelum memulai kegiatan belajar mengajar. Guru harus mempersiapkan diri sebaik mungkin diantaranya perlu melakukan persiapan sebelum mengajar, menyediakan materi dan media sebelum kegiatan belajar mengajar, memastikan bahwa peserta didik sudah siap melaksanakan proses kegiatan belajar mengajar dikelas.

Dari hasil penelitian yang telah dilakukan, penulis dapat menyimpulkan bahwa dalam membina kedisiplinan siswa, bukan hanya sebagai kewajiban dari seorang guru bidang studi didalam kelas selama proses belajar mengajar berlangsung, namun setiap berlangsungnya kegiatan dan aktivitas yang terjadi di lingkungan sekolah. Baik dalam proses belajar mengajar didalam kelas maupun diluar kelas. Kemampuan guru dalam melakukan kegiatan komunikasi yang baik dengan siswa dapat mempengaruhi proses pembelajaran dan akan memberikan hasil yang baik bagi siswa. Pada pembelajaran Guru PKn di MAN Malang 1 diharuskan mampu mengenali karakter setiap siswanya agar dapat saling berhubungan dengan baik, dengan mengenali karakter siswanya maka guru dapat mempersiapkan strategi mengajar dan materi yang tepat untuk digunakan sebagai bahan ajar kepada siswa. Selanjutnya, guru harus dapat memberikan inovasi belajar yang kreatif agar siswa tidak bosan dengan apa yang diajarkan, dengan begitu proses kegiatan belajar akan lebih menyenangkan dan siswa tidak akan bosan pada saat belajar.

\section{Kendala yang dihadapi oleh Guru PKn dalam membina kedisiplinan siswa}

Dalam membina kedisiplinan siswa, terdapat berbagai macam kendala yang dihadapi oleh guru dan pihak sekolah. Adanya suatu masalah tidak dapat dihindari, tetapi permasalahan tersebut harus dihadapi dengan sikap dan tindakan yang positif agar tidak merugikan bagi guru maupun peserta didik, dengan demikian peneliti menggali informasi kepada Guru PKn yang berkenaan dengan faktor dan kendala yang dihadapi dalam membina kedisiplinan siswa,

Sejak awal sekolah sudah mensosialisasikan tata tertib yang sudah disusun dan akan diberlakukan kepada siswa. Sosialisasi ini bertujuan agar semua pihak yang terkait mengetahui aturan-aturan yang berlaku disekolah.Sosialisasi dilakukan kepada guru, orang tua dan siswa.Sosialisasi kepada guru dapat dilakukan pada saat rapat, sementara dukungan guru diharapkan dapat memberi teladan yang baik bagi siswa. Guru merupakan orang pertama dalam penegakan disiplin sekolah juga diharapkan memberi dukungan bagi penerapan dan pelaksanaan disiplin sekolah terhadap 
siswa. Sosialisasi kepada siswa dilakukan pada saat penerimaan siswa baru, sedangkan sosialisasi kepada orang tua dilakukan setiap tahun ajaran baru. Sosialisasi terhadap orang tua biasanya dapat dilakukan dengan mengundang wali murid untuk datang ke sekolah dan menjelaskan program-program sekolah akan diberlakukan.

Peraturan dan tata tertib sekolah sudah dibuat dan sebelum diterapkan harus disosialisasikan dengan guru-guru, orang tua siswa dan siswanya sendiri, dengan adanya sosialisasi tentang peraturan dan tata tertib sejak awal kepada guru, orang tua, dan siswa maka diharapkan peraturan itu dapat dilaksanakan dengan baik dan dipatuhi oleh siswa sehingga siswa tidak akan melanggar peraturan-peraturan yang diberlakukan disekolah.

Faktor yang mendukung pelaksanaan disiplin sekolah di MAN Malang 1 ini diantaranya peraturan dan tata tertib yang diberlakukan semakin ditingkatkan lagi keefektifannya, sarana dan prasarana yang ada di MAN Malang 1 cukup baik dan memadai fasilitasnya, guru dan pihak sekolah sangat memperhatikan perilaku siswa ketika disekolah. Setiap siswa yang melanggar peraturan dan tata tertib dikenakan sanksi sesuai dengan yang diperbuat siswa.Faktor pendukung yang ada di MAN Malang 1 tersebut dikatakan sudah dapat menerapkan sikap disiplin terhadap siswanya.Tetapi didalam pelaksanaan mematuhi peraturan dan tata tertib itu siswa terkadang ada yang melanggar. Terjadinya pelanggaran tersebut merupakan tugas guru dan pihak sekolah yang menangani agar siswanya tidak melakukan pelanggaran-pelanggaran lagi, dengan adanya sanksi yang diberikan, siswa akan berusaha menata perilakunya agar terbiasa tertib, teratur dan mematuhi peraturan dan tata tertib yang berlaku disekolah. Penerapan disiplin akan mendorong, memotivasi dan memaksa peserta didik untuk meningkatkan belajar mereka disekolah, apabila kedisiplinan itu diterapkan dengan baik akan memberikan dampak yang baik bagi prestasi belajar siswa disekolah.

Dari penjelasan tersebut dapat disimpulkan bagaimana peranan guru PKn dalam meningkatkan kedisiplinan siswa itu sendiri selain didalam kegiatan proses belajar mengajar berlangsung, yaitu selama kegiatan yang dilakukan di lingkungan sekolah, baik di kelas maupun di luar kelas, dan itu bukan hanya merupakan tugas dari salah satu guru bidang studi, namun secara keseluruhan pihak-pihak yang ada disekolah.

\section{Solusi yang dilakukan oleh Guru PKn dalam mengatasi pelanggaran kedisiplinan siswa}

Dari semua permasalahan yang ada akibat kurang disiplinnya siswa sebagai faktor penghambat dan kendala dalam membina kedisiplinan, peneliti ingin mengetahui solusi apa yang seharusnya dilakukan oleh guru PKn agar peraturan dan tata tertib di MAN Malang 1 ini berjalan dengan efektif dan dapat dipatuhi oleh siswa. Disiplin tidak dapat terwujud dengan waktu yang singkat karena diperlukan usaha dan kerja keras guru bersama kepala sekolah untuk mewujudkannya. Disiplin sekolah seharunya dimulai dari hal yang terkecil misalnya aturan tentang memakai sepatu, searagam, kehadiran di sekolah, tatanan rambut, serta bawa yang dibawa.

Sejak awal sudah di sosialisasikan tentang peraturan yang dibuat harus dipatuhi oleh siswa. Peraturan tersebut sudah jelas ditujukan kepada siswa, maka sudah sepatutnya siswa mentaati setiap 
peraturan yang telah dibuat oleh sekolah agar kegiatan belajar mengajar dan bersosialisasi di lingkungan sekolah dapat lebih efektif. Dalam hal menciptakan strategi itu Kepala Sekolah merupakan orang yang paling bertanggung jawab terhadap pengembangan disiplin sekolah, dan dibantu oleh guru-guru lain.

Berdasarkan tata tertib yang sudah ditetapkan bahwa setiap siswa yang melakukan pelanggaran baik itu tentang kedisiplinan maupun melanggar peraturan tata tertib, maka mereka harus menerima hukuman/sanksi. Sanksi diberikan kepada siswa sesuai dengan pelanggaran yang dilakukan, kalau melanggar hanya sekedar membuang sampah sembarangan hanya diberikan teguran saja, Tetapi apabila terlambat datang ke sekolah, memakai sepatu diluar ketentuan dan memakai seragam yang tidak sesuai maka perlu tindakan dari guru BK dan Kesiswaan untuk menangani permasalahan siswa tersebut.

Dari hasil wawancara yang dilakukan peneliti terhadap Guru PKn, Kepala Sekolah dan Guru BK memang benar bahwa setiap siswa memiliki karakteristik yang berbeda-beda. Sebab ada beberapa faktor yang mempengaruhi perbedaan karakteristik tersebut. Bisa mulai dari lingkungan keluarga, lingkungan sekitar dan lingkungan sekolah, dari perbedaan beberapa karakteristik peserta didik, maka guru dan pihak sekolah harus bisa menerapkan peraturan dan tata tertib sekolah lebih efektif lagi, terutama permasalahan kedatangan siswa yang terlambat dan sering tidak membawa/ memakai seragam yang sesuai, serta pelanggaran-pelanggaran lain. Dalam pengembangan disiplin sekolah perlu mendapat dukungan dari berbagai pihak terutama guru dan orang tua.Guru yang setiap hari mengajar siswa dikelas dan berinteraksi secara langsung dengan siswa dapat diharapkan bisa membina kedisiplinan siswa dengan baik. Orang tua sebagai pendidik, pengawas dan pengontrol ketika dirumah juga diharapkan dapat membimbing, mengawasi dan mendidik anaknya agar tidak melakukan tindakan-tindakan yang merugikan dirinya sendiri dan orang tua. Disiplin memang sangat penting bagi setiap individu, apalagi bagi peserta didik, karena sikap disiplin yang muncul dari kesadaran diri peserta didik dalam belajar akan mnengantarkan kepada kesuksesan belajar dan suatu saat ketika bekerja, dan tentunya sikap disiplin itu didukung oleh kesadaran mentaati aturan, norma-norma dan tata tertib yang berlaku agar peserta didik menjadi individu yang tertib, teratur dan dapat diterapkan oleh peserta didik dalam kehidupannya sehari-hari.

\section{SIMPULAN}

Berdasarkan fokus penelitian, hasil penelitian dan pembahasan, maka hasil penelitian ini dapat disimpulkan sebagai berikut:Peranan Guru PKn dalam membina kedisiplinan siswa di MAN Malang 1 diantaranya berupa: Pertama, Menegakkan disiplin kepada peserta didik dengan memberikan contoh langsung kepada anak didiknya dan menjadi teladan bagi peserta didik yaitu dengan datang tepat waktu. Sebab peserta didik selalu meniru apa yang dilakukan oleh gurunya, dengan melihat gurunya disiplin maka peserta didik akan membiasakan dirinya untuk selalu bersikap dan berperilaku disiplin disekolah.Kedua, Mengawasi perilaku peserta didik dalam setiap aktifitasnya dengan mengawasi perilaku anak didiknya. Guru PKn memiliki peranan yang luas dalam membina kedisiplinan 
siswa-siswinya pada saat ia menyampaikan materi maupun diluar kegiatan belajar mengajar dengan begitu Guru PKn dapat mengetahui permasahan-permasalahan yang ada pada anak didiknya. Ketiga, Selalu menanamkan sikap disiplin kepada peserta didik secara terus-menerus agar menjadi kebiasaan yang baik bagi anak didiknya dan memberikan sanksi kepada siswa yang melakukan pelanggaran tentunya sanksi tersebut bersifat menguntungkan dan mendidik bagi siswa, dengan adanya sanksi tersebut siswa akan merasa jera terhadap sanksi yang diberikan dengan tidak terlambat lagi sehingga menjadikan peserta didik lebih disiplin dalam bertingkah-laku disekolah.

Kendala yang dihadapi oleh Guru PKn dalam membina kedisiplinan siswa diantaranya adalah:Pertama, Peraturan tata tertib sekolah kurang disadari oleh peserta didik dan peserta didik masih melakukan pelanggaran dengan begitu Guru PKn selalu berusaha mencari tahu penyebab keterlambatan anak didiknya karena itu merupakan bentuk dan rasa tanggung jawabnya sebagai seorang pendidik.Kedua, Masih kurang adanya komunikasi antara pihak sekolah dengan orang tua siswa, disamping itu kendalanya dari faktor eksternal/pengaruh teman-temannya diluar anak MAN Malang 1 sehingga peserta didik cenderung melakukan pelanggaran. Ketiga, Belum semua guru mengingatkan ke siswa sehingga kedisiplinan ini masih terpaku pada petugas tatib karena keteladanan disiplin Kepala Sekolah serta Guru-guru dan karyawan MAN Malang 1 sangat berpengaruh terhadap disiplin peserta didik, mereka lebih mudah meniru apa yang mereka lihat dibanding apa yang mereka dengar.

Solusi yang dilakukan oleh Guru PKn dalam mengatasi pelanggaran kedisiplinan siswa diantaranya adalah:Pertama, Guru PKn melakukan pendekatan dan memberi teguran kepada peserta didikyang sering melakukan pelanggaran dengan mendekatinya dan memberikan nasihat yang dapat diterima oleh peserta didik sehingga anak didiknya tidak melakukan pelanggaran-pelanggaran lagi ketika disekolah serta berupaya agar siswa yang sering terlambat masuk kelas pada saat mata pelajaran PKn tidak melakukan pelanggaran lagi, jika siswa masih mengulangnya maka Guru PKn bertindak dan bekerjasama dengan orang tua peserta didik agar anak didiknya tidak mengulang lagi perbuatannya karena merugikan dirinya dan dapat mempengaruhi temannya yang lain. Kedua, Guru PKn Mendekati peserta didik dan memberi masukan kepada peserta didik untuk selalu berperilaku disiplin dan melakukan pengawasan dan pembinaan terhadap peserta didik untuk mencegah dan mengatasi tindakan yang melanggar peraturan tata tertib sekolah.

Ketiga, Guru PKn mencari tahu permasalahan yang ada pada diri peserta didiksehingga menyebabkan peserta didik sering melakukan pelanggaran, dan memberikan solusi yang baik kalau tidak ada perubahan maka Guru PKn bertindak langsung dengan berkomunikasi dengan orang tua siswa dan bekerjasama supaya peserta didik tidak melakukan pelanggaran disekolah.dan tentunya pihak sekolah juga serta guru-guru dan karyawan yang ada di MAN Malang 1 berupaya agar saling kerjasama dalam membina kedisiplinan siswa. Keempat, Upaya yang dilakukan oleh pihak sekolah terhadap permasalahan kedisiplinan siswa disekolah yaituperlu adanya komunikasi antara pihak sekolah dengan semua guru-guru dan karyawan termasuk orang tua siswa dan perlu adanya sosialisasi.Sosialisasi dilakukan kepada 
guru, orang tua dan siswa secara terusmenerus, sosialisasi dilakukan dengan tujuan agar semua pihak yang terkait mengetahui aturan-aturan yang berlaku disekolah.

Dari hasil penelitian terhadap peranan Guru PKn dalam membina kedisiplinan siswa MAN Malang 1, maka penulis memberikan beberapa saran sebagai berikut:Guru PKn dapat memberikan pendekatan dan pengawasan secara terusmenerus kepada peserta didik apabila peserta didik masih mengulang perbuatannya yang sering melakukan pelanggaran-pelanggaran disekolah dan siswa yang sering terlambat masuk kelas pada saat mata pelajaran PKn berlangsung dengan begitu guru dapat bertindak dan melaporkannya kepada orang tua/wali serta dapat mengatasinya dengan baik agar mencegah perilaku ketidak disiplinan mereka.

Guru PKn harus memberikan motivasi kepada peserta didik agar meningkatnya semangat belajar mereka agar anak didiknya selalu berperilaku disiplin disekolah maupun diluar lingkungan sekolah dan memberikan contoh dalam berdisiplin yaitu dengan selalu datang tepat waktu karena peserta didik biasanya selalu meniru yang dilakukan oleh gurunya

Tidak hanya Guru PKn saja yang berperan dalam meningkatkan kedisiplinan siswa di MAN Malang 1 tetapi semua guru mata pelajaran itu harus bertanggung jawab dan berperan aktif terhadap kedisiplinan peserta didik. Guru harus menghindari kebiasaan yang tidak tepat waktu agar anak didiknya tidak melakukan pelanggaran. dengan meningkatkan dan memberi pembinaan, pengawasan yang ketat kepada peserta didik, perhatian yang kuat serta keteladanan semua Guru-guru dan karyawan yang ada di MAN Malang 1.
Kepala Sekolah harus lebih meningkatkan pengawasan dan pengarahan tehadap seluruh guru mata pelajaran agar selalu berkoordinasi untuk selalu bersamasama membina disiplin siswa

Untuk meningkatkan pembinaan kedisiplinan peserta didik maka dari itu pihak sekolah melakukan kerjasama dan komunikasi dengan berbagai pihak seperti orang tua, siswa dan seluruh guru dan karyawan yang ada di MAN Malang 1 dalam memecahkan masalah yang dihadapi dalam upaya peningkatan kedisiplinan siswa.

Pihak sekolah juga harus lebih mengefektifkan lagi tata tertib tersebut dan memberlakukan peraturan tata tertib yang lebih tegas lagi sehingga mudah untuk diikuti dan mampu menciptakan suasana yang kondusif dilingkungan sekolah. Pembiasaan disiplin disekolah akan mempunyai pengaruh positif bagi kehidupan siswa dimasa mendatang. Pada mulanya memang disiplin dirasakan sebagai sesuatu yang mengekang kebebasan. Akan tetapi, bila aturan ini dirasakan sebagai sesuatu yang memang seharusnya dipatuhi secara sadar untuk kebaikan dirinya dan sesama, lama-kelamaan akan menjadi suatu kebiasaan yang baik menuju arah disiplin pada diri siswa.

Sekolah sebagai tempat menimba ilmu maka diperlukan segala fasilitas yang mendukung untuk kenyamanan siswa belajar disekolah, dengan adanya sarana dan prasarana dan fasilitas yang disediakan oleh sekolah maka siswa akan merasa aman dan nyaman sehingga kegiatan belajar mengajar dapat berjalan dengan efektif. 


\section{DAFTAR PUSTAKA}

Moleong, Lexy J. 2011. Metodologi Penelitian Kualitatif (Edisi Revisi). Bandung: PT. Remaja Rosdakarya.

Mulyasa, E. 2013. Menjadi Guru Profesional Menciptakan Pembelajaran Kreatif dan Menyenangkan. Bandung: PT. Remaja Rosdakarya.

Prijodarminto, Soegeng. 1994. Disiplin Kiat Menuju Sukses. Jakarta: Abadi.

Saardiman A.M 2010. Interaksi dan Motivasi Belajar Mengajar.Jakarta: Rajawali Pers.

Slameto. 2013. Belajar dan FaktorFaktor Yang Memperngaruhi. Jakarta: Rineka Cipta.

Sugiyono. 2012. Metode Penelitian Pendidikan (Pendekatan Kuantitatif, Kualitatif, dan $R \& D)$. Bandung: Alfabeta.

Sutirna. 2013. Bimbingan dan Konseling (Pendidikan Formal, Nonformal dan Informal).Yogyakarta: Andi.

Tu'u Tulus. 2004. Peran Disiplin pada Perilaku Siswa dan Prestasi siswa. Jakarta: Gramedia.

Winarno. 2013. Pembelajaran Pendidikan Kewarganegaraan (Isi, Strategi, dan Penilaian) Jakarta: PT. Bumi Aksara. Zuriah, Nurul. 2009. Metodologi Penelitian Sosial dan Pendidikan (Teori Aplikasi). Jakarta: PT. Bumi Aksara.

Sumber internet:

Dodi Supandi : http://blogspot.com/2010/ 05/24karakteristik-pendidikan.html (Diakses pada tgl 31 November 2014)

Mashun: http://blogspot.com/2013/11/ tugas-dan-tanggung-jawab-guru.html (Diakses pada tgl 29 November 2014) 